
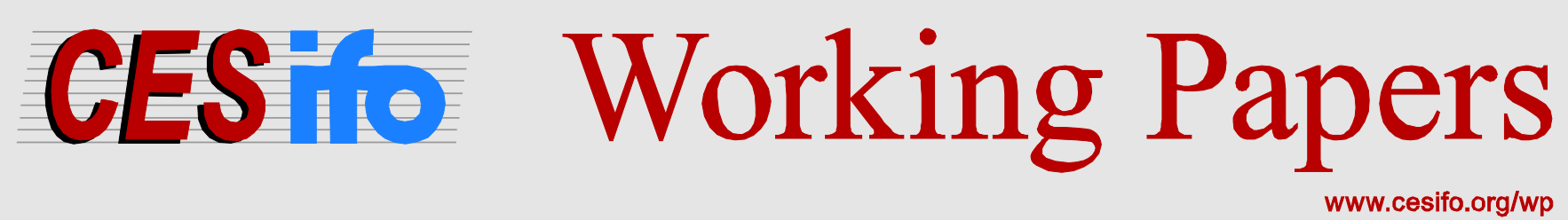

\title{
Natural-Resource Rents and Internal Conflicts - Can Decentralization Lift the Curse?
}

\author{
Mohammad Reza Farzanegan \\ Christian Lessmann \\ Gunther Markwardt
}

CESIFO WORKING PAPER NO. 4180

CATEgory 2: Public CHOICE

MARCH 2013

An electronic version of the paper may be downloaded
- from the SSRN website:
- from the RePEc website:
from the CESifo website: 


\title{
Natural-Resource Rents and Internal Conflicts - Can Decentralization Lift the Curse?
}

\begin{abstract}
We study how natural-resource rents affect the risk of internal conflict within countries and how the federal structure of countries influences this relationship. Natural-resource abundance may induce excessive rent-seeking and thus increase the risk of internal conflict. Fiscal and political decentralization as an institutional arrangement for rent-sharing and political codetermination of regions within a country may limit the destructive effect of the naturalresource rents on internal stability. Using cross-country and panel data covering the period 1984-2004 from more than 90 countries, we find evidence that natural-resource rents indeed increase the risk of internal conflict, but this relationship is significantly mitigated by decentralization.
\end{abstract}

JEL-Code: H770, P480, Q340, Q380.

Keywords: natural resources, risk of conflict, decentralization.

\author{
Mohammad Reza Farzanegan \\ Philipps-University Marburg \\ Marburg / Germany \\ farzanegan@staff.uni-marburg.de
}

\author{
Christian Lessmann \\ Dresden University of Technology \\ Dresden / Germany \\ christian.lessmann@tu-dresden.de
}

\author{
Gunther Markwardt \\ Dresden University of Technology \\ Faculty of Business and Economics \\ Germany-01062 Dresden \\ gunther.markwardt@tu-dresden.de
}

This version: March 2013

We are grateful to Lars-Erik Borge, Raphaël Franck, Constance Smith, Marcel Thum, the session participants at the 68th annual congress of the IIPF, the participants in the brown bag seminars at TU Dresden and ZEW Mannheim, and the participants in the 5th CESifo Workshop on Political Economy for many useful comments. 


\section{Introduction}

In this study we analyze the link between natural-resource rents and the risk of internal conflict and how the federal structure of countries influences this relationship. In doing so, we combine two strands of literature: the literature on the nexus between natural resources and conflict, and the literature on the nexus between decentralization and conflict. As a key result we find that higher natural-resource rents increase the risk of internal conflict, but the risk-increasing effect of resources is moderated by decentralization.

Internal conflicts such as civil war, coup, terrorism, political violence, and civil disorder have enormous costs for individuals and governments. Such costs include damage to public infrastructure, factories, and private fortunes, and physical and mental injuries, as well as indirect costs such as population displacement and reduction in human capital. Political instability and internal conflicts increase the risk for domestic and foreign investors and thereby have direct negative effects on investments. Capital flight and reduced foreign direct investment harm the economic growth of countries and might further boost the risk of internal conflict. Estimations by Collier (1999) show that during civil wars, countries tend to grow, on average, 2.2 percentage points slower than in peacetime. Stewart et al. (2001) examined 18 countries that experienced an internal conflict and show that per capita income drastically decreased, food production decreased, and the external debt burden increased significantly. ${ }^{1}$ However, for the economic consequences of internal conflict, not only the most extreme form of conflict - civil war - is relevant, but also the risk of internal conflict emerging from other sources of violence, in particular terrorism and civil unrest. Therefore, we focus - in contrast to the existing literature - on the risk of internal conflict rather than explaining the onset, the incidence, or the duration of civil war. Figure 1 illustrates the negative association between the risk of internal conflict [from Political Risk Services (PRS)] and the GDP per capita in our sample of countries. This risk indicator ranks countries by their joint risk of civil war, terrorism, and civil unrest [see section 4.1 for further details]. The figure clearly suggests that high-risk countries, on average, are less developed. Using the average growth rates instead of the development level does not substantially alter the picture.

A main channel that fuels internal conflict is the competition for natural-resource rents [Ross (2004)]. Inequality in the distribution of natural resources among different groups (e.g., political factions or ethnic groups) fuels tensions and destructive competition for such rents. This means that resources by themselves are not responsible for conflicts, but there are other social and economical bottlenecks, which make resource rents a

\footnotetext{
${ }^{1}$ Collier et al. (2003) has a comprehensive examination of civil-war-related case studies.
} 


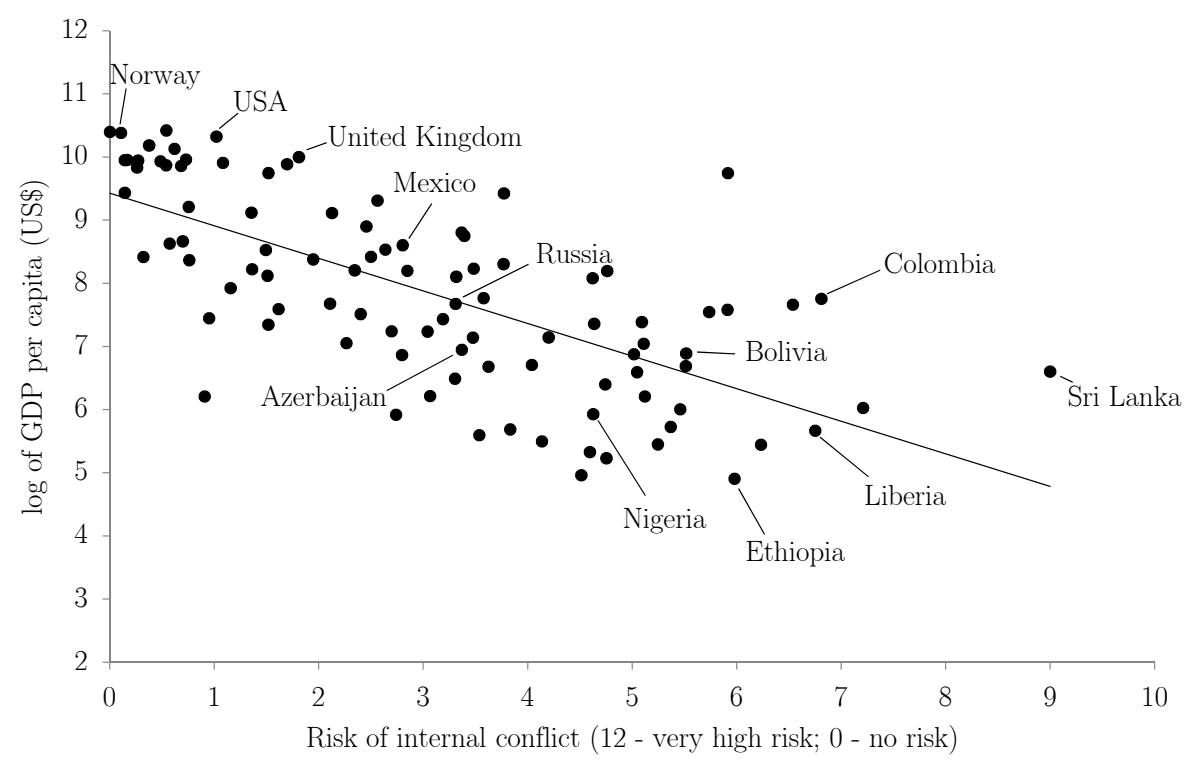

Figure 1: Conflict and economic development (1984-2004)

ground for internal battles. Poverty, ethnic or religious grievances, and fragile political institutions are among these conditioning factors in the resource-rent-conflict nexus. Fearon and Laitin (2003) and Fearon (2005) discussed the effect of resource rents on the quality of governance, calling it "a political Dutch disease". They show a destructive role of point resources on the state capacity, which then fuels internal conflicts. Collier and Hoeffler $(1998,2004)$ show that countries that are rich in natural resources face a higher probability of civil war. Fearon (2004) and Soysa (2002) emphasize the destructive role of oil resources for peace. Most parts of previous literature find a strong correlation between natural-resource wealth and internal conflicts. We aim to bring this literature together with the literature on decentralization, which might affect the resource-rent-conflict nexus.

For this purpose, we analyze a panel of 91 countries covering the period from 1984 to 2004. We can show that, in particular, higher oil and gas rents per capita increase the risk of internal conflict, controlling for other determinants of conflicts. Having found this connection, we proceed to suggest a mechanism to moderate these effects. We find empirical evidence that, in particular, political decentralization significantly reduces the risk of internal conflict caused by natural-resource rents. This may be related to the higher accountability of politicians in decentralized countries, to better representation of the people in politics, and to revenue-sharing rules.

The rest of the paper is organized as follows. Section 2 examines the two strands of literature: the theoretical discussions on (1) the resources-conflict nexus and (2) the decentralization-conflict nexus. Based on these separate analyses, our study connects 
the two strands of the literature. In section 3 we briefly survey the previous empirical literature on both topics. Section 4 describes the data, explains the empirical strategy, and presents our estimation results. Finally, section 5 summarizes and concludes the paper.

\section{The nexus between natural-resource rents, internal conflicts, and decentralization}

Our study is related to two strands of the literature: the literature on the nexus between natural resources and conflict, and the literature on the nexus between decentralization and conflict. In the following, we briefly review the theoretical arguments in the two parts of the literature separately. We subsequently combine the theoretical arguments and discuss how decentralization can affect the relationship between natural-resource rents and conflict.

\subsection{Natural resources and internal conflict}

There is a comprehensive literature on the relationship between natural resources and conflict. The main body of studies on this topic is empirical. ${ }^{2}$ Some of these studies do not provide details on the underlying theoretical framework. As to this, we aim to be more precise, in that we will focus on the interaction of natural-resource rents and decentralization in our empirical analysis; therefore the underlying mechanisms are of great interest. Following, we give a brief overview on the main arguments for the theoretical linkages between natural resources and conflict.

Collier and Hoeffler (2012) discuss several channels that connect natural resources with unfulfilled potential for economic growth and risk conflict. The main arguments are: (1) access to honeypots, (2) secessionists movements, (3) the financing of rebel groups, (4) the isolation of the governments from their electorates, and (5) poor economic development due to the Dutch disease.

The exploitation of (or future access to) natural resources generates a valuable honeypot over which different groups may fight. Fearon and Laitin (2003) argue that natural resources increase the prize value of capturing the state, thereby increasing the potential gains to rent-seeking activities and the risk of conflict. ${ }^{3}$ A second, closely related argument concerns secessionist movements. Since natural resources are usually not uniformly distributed within a country, the well-endowed regions can credibly seek

\footnotetext{
${ }^{2}$ Notable exceptions are, e.g., Sánchez-Pagés (2006), Wick and Bulte (2006), and Janus (2012).

${ }^{3} \mathrm{~A}$ similar argument can be made for foreign aid or other kinds of windfall profits. However, in contrast to natural resources, donors can adjust aid flows in conflict situations. This uncertainty reduces the expected gains from rebellion.
} 
economic and political independence from other parts of the country. This unequal distribution of natural resources can be an important reason for political instability and conflicts [see, e.g., Ross (2004) or Le Billon (2001)].

Third, every conflict has to be financed. Natural resources are an important source of financing of conflicting parties. Rebel groups usually have no regular access to the government budget. They may finance their military and political activities through criminal proceeds from kidnappings or protection rackets, through the diversion of foreign aid, through diaspora remittances, and, of course, through revenues from trading natural commodities [Le Billon (2001)]. The access to natural-resource rents allows rebel groups to finance themselves, and hence continue fighting independently of other sources of finance. Ross (2004) argues that lootable resources may make conflicts so profitable that rebel groups actually lose their incentive to reach a peace settlement.

The fourth argument is that natural-resource rents detach the governments from their electorates. Representative governments arise because states need the compliance of taxpayers to finance their tasks by tax revenues [Acemoglu and Robinson (2000)]. Resource rents are by definition non-tax revenues and reduce the accountability of governments. The reduction of government accountability and the lower participation of citizens increase the risk of conflict.

The last argument to be discussed is poor economic development due to the Dutch disease. Here, the transmission channel between natural resources and the risk of conflict is a more indirect one. An increase in natural-resource revenues raises the exchange rate and thereby makes the manufacturing sector less competitive [see Corden and Neary (1982)]. If the manufacturing sector is the engine of economic growth due to the larger opportunities for technical innovations than in the resource sector, the growth rates will decline and may result in a resource curse. The literature has shown that low growth rates are significantly related to a higher risk of conflict [see, e.g., Collier and Hoeffler (2004) or Collier et al. (2009)]. The effect is even stronger if the resource curse results in more unequal economic development within a country, which will further increase the risk of conflict [Østby et al. (2009), Buhaug et al. (2012), and Lessmann (2013)]. All these arguments are evidence for the hypothesis that natural resources increase the risk of internal conflict. But, of course, natural resources may also lower the probability of internal conflict if they are used to build state capacity [Besley and Persso (2010)]. A strong state with good institutions can balance the economic inequalities and thus reduce the risk of conflict. 


\subsection{Decentralization and internal conflict}

Apart from the literature on natural resources and conflict, there is an ongoing discussion of the role of decentralization and federalism in economic growth and conflict. Decentralization is defined as the transfer of political and fiscal power and responsibilities from a central government to sub-national jurisdictions. The trend of decentralization and its popularity among developing countries' policy makers is increasing. International organizations such as the World Bank encourage decentralization reforms, asking aid recipients to implement political and fiscal decentralization projects. Decentralization lowers the risk of internal conflicts if (1) it improves public services, (2) it is better acquainted with the local causes of conflict, (3) it facilitates participation and codetermination by minorities, (4) it enables the reconstruction of failed states from the bottom up, and (5) it has a redistributive effect between the different regions [see Schou and Haug (2005) and GTZ (2006)].

The first argument is related to the positive effects of decentralization on governance. Decentralization closes the gap between the government and the people, since local officials are better informed on local needs, and are thus more capable of providing the preferred mix of public services. This increase in efficiency contributes to economic growth, particularly in an economy with heterogeneous regions [Oates (1972)]. If the local needs and preferences are different from the national interests, decentralization may increase local welfare, and the increase in welfare is negatively associated with the risk of conflict.

Closely related is the second argument. Local authorities are better informed of the causes of local conflicts. Decentralization can reduce information asymmetries and provides instruments to balance local interests and prevent conflicts.

The third argument in favor of decentralization is that decentralization allows ethnic minorities to control their own affairs, whilst the geographical integrity of the coun-

try is maintained [Brancati (2006a)]. Decentralization strengthens the elements of self-determination and political participation for minorities through a set of legal frameworks. This increases the legitimation and acceptance of the state by minorities, and may reduce the demands for autonomy and secessionist movements.

The fourth argument concerns the reconstruction of failed states. Sub-national governments have the necessary proximity to the local population, as well as the organizational and spatial capacities, to rebuild failed states from below. This bottom-up reconstruction process ensures civic participation and the provision of the necessary public services at the local level, which reduces the risk of new conflicts [see GTZ (2006), p. 7]. 
The last beneficial effect to be discussed is the redistributive effect of decentralization. In many cases, decentralization not only increases competition and self-reliance among regions, but also includes redistributive elements. Decentralization may give poor regions the necessary political autonomy and authority to implement policies that allow them to compete with rich regions for mobile factors (e.g., tax holidays). These redistributive effects of decentralization may lower interregional inequalities within countries [Baldwin and Krugman (2004) and Lessmann (2012)]. In addition, interregional transfers, which are often part of the federal system, insure the regions against asymmetric shocks [Persson and Tabellini (1996)]. The more equal distribution of resources at the local level may increase stability both at the local and at the national level [Schou and Haug (2005)]. Therefore, the insurance element of decentralization promotes social development and cooperation amongst different groups and different regions, and thus increases the national cohesion and reduces the risk of internal conflict.

In contrast to these beneficial effects, the literature points out that decentralization may also fuel conflicts. Decentralization can increase the risk of conflict if (6) the central government loses its arbitrator role, (7) it results in unequal regional development [Prud'homme (1995)], or (8) it results in local autocracy [GTZ (2006)].

A strong and representative central government is able to balance the interests between different groups and regions. With strong institutions or even with military power, a central government can prevent conflicts and enforce peace. In many cases, a central government is seen as taking a neutral position in local conflicts [GTZ (2006)]. Decentralization shifts the balance of power to the local level, and thereby weakens the position and the competence of the central government. Since local governors are usually more accountable to local electorates in decentralized systems, they may take positions to defend the local interests at the cost of national interests. In this case, decentralization provides new institutional and economic resources to the separatist movements. As a result, decentralization may foster conflicts instead of preventing them [Tranchant (2010)]. The competitive elements of decentralization also may lead to unequal regional development. The transfer of competences to the local level may lead to very different political and economic solutions and results. In particular, if the initial conditions within a country are very heterogeneous, decentralization may exacerbate the differences between regions. In this case, the national cohesion will decrease and the risk of internal conflict will increase. As Rémy Prud'homme puts it: "decentralization can be the mother of segregation" [Prud'homme (1995), p. 203].

The last argument concerns the danger of local autocracy. If the preferences of groups at the local level differ widely from those at the national level, political decentralization can have serious implications for the power relationships between local majorities and national majorities. Regional parties may intensify conflicts and secessionist move- 
ments by reinforcing ethnic and regional identities [Brancati (2006a)]. The augmenting effect of decentralization on internal conflicts can also occur through higher political factionalism or polarization. Under a decentralized system creating a contentious atmosphere, it may be difficult to find solutions for policy differences [Marshall and Gurr (2005)]. Corruption in decentralized countries may also foster local-elite capture [Bardhan (2002)], which then increases the vulnerability of the system.

Our preliminary conclusions: The majority of arguments suggest that natural resource increase the risk of internal conflict. Regarding the effect of decentralization, however, the theoretical predictions are not conclusive. In the next section, we combine the arguments of the two strands of literature. Thereby, we clarify the linkages between natural resources, decentralization, and the risk of conflict.

\subsection{Decentralization as potential moderator or catalyst for resource conflicts}

Not all of the presented arguments regarding the relationship between natural resources and conflict and between decentralization and conflict can be combined. But some arguments are directly connected. The linkages are particularly strong for arguments regarding the relationship between the governments and their electorates, and for the insurance effect of decentralization. Less closely related are the arguments concerning the effects of the lower economic development due to the Dutch disease and decentralization. The question of the effective direction of the interaction of natural resources and decentralization with respect to secessionist movements or the financing of rebel groups is ambiguous. Both a fueling and a damping effect on the risk of conflict are possible. In this connection, we aim to show that decentralization can be an important moderator for the effect of natural resources on the risk of internal conflict.

Decentralization may decrease the negative effect of natural-resource rents on the risk of internal conflict, if decentralization increases the accountability of the governments to the citizens of the country. As discussed in section 2.1, non-tax revenues - in our context natural-resource revenues - detach the governments from their electorates. Decentralization increases the proximity between taxpayers and policy makers, thereby increasing the transparency of political decisions. Moreover, when local elections enable the taxpayers to punish local decision makers for a bad policy, decentralization increases their accountability and dampens the effect of natural-resource rents in increasing the risk of conflict.

A second important link is the mutual insurance of regions. Natural resources are usually not uniformly distributed over a country. The economic performance of wellendowed regions depends highly on resource incomes. Therefore, these regions are often exposed to price shocks. Negative price shocks often result in severe economic 
downturns. Decentralization combined with a formal equalization scheme can balance the risk of price shocks and may lead to a more equal development of regions. In this case decentralization increases the national cohesion, which might reduce the risk of internal conflict through a more balanced distribution of factors among the different regions. This is particularly important if point resources are a major source of revenue within a country.

Another important argument in favor of decentralization is increased public sector efficiency. This increase in efficiency contributes to economic development and growth and may offset the negative effect of the natural resources due to the Dutch disease. Although the transmission channel is more indirect, this implies that decentralization may compensate the negative effects of natural resources on the risk of internal conflict.

Concerning the other theoretical arguments, we cannot identify unambiguous effects of decentralization. Both natural resources and decentralization give more room for secessionist movements. On the one hand, decentralization strengthens the elements of self-determination and political participation for minorities. Self-determination and resource rent-sharing between different groups and regions may be beneficial for conflict prevention and conflict resolution. This increases the acceptance of the state by minorities, and may reduce the demands for autonomy and secessionist movements. On the other hand, decentralization creates the political conditions for autonomy, since it equips the regions with many necessary governmental institutions facilitating the step to independence. If natural-resource rents provide the financial basis for such a development, the interaction of decentralization and natural resources may foster secessionist movements and increase the risk of internal conflict.

Our discussion shows that the theoretical literature implies that both natural resources and decentralization affect the risk of internal conflict. Concerning the effect of decentralization on the tendency of natural resources to increase the risk of conflict, the theory is ambiguous. Decentralization can either moderate or increase that tendency. In light of these multifaceted arguments, the aim of our paper is to empirically investigate the link between natural-resource rents and the risk of internal conflict and how the federal structure of countries influences this relationship. In the next section we briefly survey both strands of the previous empirical literature.

\section{A review of the previous empirical literature}

The disappointing performance of resource-rich economies (especially those with a point or lootable resource such as oil) draws our attention to the hypothesis of a naturalresource curse. The literature on this subject is concerned with the puzzling role of 
natural resources in economic growth. Robinson et al. (2006) define the resource curse as a situation where a boost in the natural-resource rents leads to a lower GDP. It is common wisdom that those countries rich in natural resources, in particular oil, are suffering from lower economic growth than those without such resources [see Sachs and Warner $(1995,2001)]$. However, the literature on this subject is not fully conclusive. Indeed, there are two different findings in it.

The first group of studies emphasizes a strong negative direct association between resource wealth and growth [see, e.g., Sachs and Warner (2001), using natural-resource exports in GDP as a proxy for resource abundance, and Iimi (2007), using mineral exports per capita]. Boschini et al. (2007) and Mehlum et al. (2006) show that this negative association is stronger for minerals than general resources. The second, more recent studies undermine the former group, arguing that the direct effect is positive. For example, Brunnschweiler (2008) uses natural-resource wealth data of the World Bank and estimates a positive and statistically significant effect of this proxy of natural wealth on economic growth, controlling for the quality of institutions among other factors. Alexeev and Conrad (2009) estimate cross-country regressions, indicating that oil revenues have been on balance positive for growth. They conclude that there is an "elusive curse of oil".

Because of these ambiguities in the growth-resource literature, we focus on the link between resources and internal conflict. Internal conflicts are a major cause of poor economic growth, as the figure in the introduction illustrates. Focusing on this particular argument might help to understand the data. There is a comprehensive literature with evidence on the negative effect of civil war and other internal conflicts on economic growth. ${ }^{4}$ Such conflicts reduce the levels of physical and human capital, which are necessary inputs for production. Hence, the level of investment falls during internal conflicts. For example, Chamarbagwala and Morán (2011) shows that Guatemala's civil war had a strong negative effect on the education of rural Mayan males and females. In another study, Shemyakina (2011) shows that as a result of civil war in Tajikistan, women get less secondary education than men. Civil wars also increase uncertainty in the local economy, leading to capital flight and worsening balance of payments in an affected country. Such conflicts also lead to misallocation of economic resources to military spending rather than social services and education. Internal conflicts also affect fiscal policies by shortening the time horizon of the ruling party. Alesina and Tabellini (1990) show that the fear of losing political power and the polarization of the country lead to a higher budget deficit of the government.

In addition to debates on the growth effects of internal conflicts, we can observe another

\footnotetext{
${ }^{4}$ See Collier et al. (2003) for a detailed review of the economic and social costs of civil wars, and Blattman and Miguel (2010) for an extensive survey of the causes and consequences of civil war.
} 
line of literature, which focuses on natural-resource-induced conflicts. This line of literature explains the link between dependence on or abundance of natural resources and the probability of internal conflict [see Ross (2004), Collier and Hoeffler (2005) Fearon (2005), Humphreys (2005), Lujala (2010), and Andersen and Aslaksen (2012)].

The growth effect of decentralization is controversial. The so-called Oates decentralization theorem implies that decentralization increases the accountability of local government to the residents' demands, raising efficiency and consequently economic growth [see Oates $(1972,1993)]$. Iimi (2005) presents supporting empirical evidence for the positive growth effects of fiscal decentralization for a sample of 50 countries from 1997 to 2001. However, several empirical studies show that fiscal decentralization increases fiscal imbalance and lowers economic growth [de Mello (2000) and Davoodi and Zou (1998)]. Decentralizing the fiscal system and political authorities may increase opportunistic behavior, if the necessary institutions are missing or functioning poorly [see, e.g., Lessmann and Markwardt (2010)]. Ebel and Yilmaz (2003) undermine the findings on negative growth effects of decentralization. They show that these findings are sensitive to the selection of decentralization-related indicators.

Furthermore, the literature is not conclusive on the ultimate effect of decentralization on national unity and conflict [Bird (2010)]. In an empirical analysis of a sample of 13 democratic countries from 1985 to 2000, Brancati (2006b) shows that decentralization can either reduce or increase conflict. Decentralization can reduce internal conflicts if regional parties do not dominate the political system. The decreasing effect of decentralization on conflict is due to closer contact of local governments with the local residents, increasing their opportunity to participate in the government. In another empirical investigation, Bermeo (2005) shows that minorities in federal states have significantly lower incentives to engage in violent activities and that federal countries face half the number of civil conflicts that unitary states face. Also, Saideman et al. (2002) show that while federal countries experience fewer rebellions, they have more protests. Pro-decentralization scholars emphasize the successful experience of countries in Asia, Africa, and Latin America, while their opponents refer to the unsuccessful experience of eastern European countries in their approach to decentralization and to the control of conflicts. Tranchant (2007) shows that decentralization can be an effective peace-building mechanism for low and moderate conflicts. His study also emphasizes the "checks and balances" at the regional levels, which reduce the possible harm to local minorities during decentralization.

An increasing effect of decentralization on internal conflicts can result from higher political factionalism or polarization. Under a decentralized system, a deliberative environment to find solutions for policy differences is difficult to achieve [Marshall and Gurr (2005)]. Since in decentralized systems local governors are usually more 
accountable to local electorates, they may take positions to defend the local interests at the cost of national interests. Corruption in decentralized countries may also foster local elite capture [Bardhan (2002)], which then increases the vulnerability of the system under decentralization. Inequality, a potential driver of internal conflict, can be greater under decentralized systems [Linz and Stepan (2000)].

There may also be an interesting more indirect link between decentralization and internal conflict. A large literature has shown that decentralization leads to lower interregional inequalities within countries, at least in high-income economies [see, e.g., Shankar and Shah (2003), Rodríguez-Pose and Ezcurra (2010), and Lessmann (2009, 2012)]. At the same time, recent literature shows that interregional inequalities are a major cause of internal conflict [Østby et al. (2009), Buhaug et al. (2012), Deiwiks et al. (2012), and Lessmann (2013)].

Finally, there is also a literature on decentralization and terrorism, which is a particular type of internal conflict. Frey (2004) argues that decentralization decreases the (political) benefits of terror attacks, which ceteris paribus decreases the attractiveness of attacks. The major driver of this result is the argument that decentralized countries have more potential targets for attacks, which are less attractive to attack than in centralized countries. Dreher and Fischer (2010, 2011) provide empirical evidence on this hypothesis.

We would like to emphasize that there is no empirical investigation of the joint effect of natural-resource rents and decentralization on the risk of internal conflict. As discussed in the previous section, the main question is whether federal systems perform better than unitary states in channelizing the resource rents into productive fields and reducing inequality and other drivers of internal conflicts. Our paper aims to fill this gap by providing an empirical analysis of the intermediary role of political and fiscal decentralization in the natural-resource-conflict interaction. In the following we test whether decentralization reduces or increases the negative externalities of resource rents on the internal stability, ceteris paribus.

\section{Empirical analysis}

\subsection{Data}

Our measure of the risk of internal conflict is provided by the PRS Group's International Country Risk Guide, available since 1984. The index is based on an annual survey of experts, who rate a country's risk of conflict in three categories: (a) civil war/coup threat, (b) terrorism/political violence, and (c) civil disorder. The highest rating is 
given to those countries where there is no armed or civil opposition to the government and the government does not indulge in arbitrary violence, direct or indirect, against its own people. The lowest rating is given to a country embroiled in an ongoing civil war. The risk rating assigned is the sum of the three components, each with a maximum score of 4 points and a minimum score of 0 points. A score of 4 points equates to very low risk, and a score of 0 points to very high risk. Thus, the index ranges from 0 to 12 , whereby the highest score indicates no risk of internal conflict. We rescale the index in such a manner that the highest value is given to the countries with the highest risk of internal conflict, to make interpretation of results easier.

The major reason for using this scheme of rating data is that it combines more dimensions of internal conflicts than raw data on terrorist attacks or civil wars, which have frequently been used in the literature. Terrorism has several causes other than natural resources. For example, a high degree of religious fractionalization or the suppression of ethnic minorities increases the risk of terrorist attacks and civil war [Esteban et al. (2012a)]. Think of Ireland or Spain, where natural resources are comparatively scarce. Similarly, civil wars have many causes. In our observation period starting in the 1980s, there are several countries facing civil wars caused by ethnic conflicts, such as Peru, Bosnia-Herzegovina, or Sri Lanka. On the contrary, Algeria (1990s), Chad (2005-2006), the Republic of Congo (1998-2004), Indonesia (1976), and Sudan (1983) are examples of resource-rich countries where the civil wars were significantly related to the resource endowments [see Ross (2004)]. Of course, in these examples ethnic diversity also played a role in the conflict, but an important motivation of the conflicting parties was to secure access to the natural resources. The advantage of the ICRG index is that it considers both terrorism and civil wars. Moreover, it is not just a binary event variable. The surveyed country experts rate the risk of conflict on a scale, where the threat of conflicts is also taken into consideration. This is an important point for the economic consequences. Increasing risk of terrorist attacks, civil wars, and civil disorder will discourage investments by foreigners and locals. Foreign investors are particularly afraid of expropriation and deterioration of the physical capital in the conflict-ridden countries, while locals increase military and security expenditures. Consequently, the capital stock and economic growth will be lower the higher the risk of conflict. For these negative economic consequences, it is not necessary that armed conflicts break out - the threat of conflict is problematic enough. For this reason, we refrain from using data on the onset of civil wars or terror data.

Our theoretical considerations exposed in section 2 emphasize the role of resource rents in conflicts. The conflicting parties compete for the financial benefits from the resource extraction, so that a measure of resource rents is more appropriate for our purpose than data on resource revenues or exports. The rent is defined as the difference between the 
output value of nonrenewable resources and intermediary consumption (or intermediary costs). The net value shows us the value-added amount of the respective resources, which are oil, gas, and timber in our context. This variable measures the amount of point-source resources or "lootable" resources [see Isham et al. (2005) and Mehlum et al. (2006)]. The World Bank (2010) calculates this variable using the following equation:

$$
\begin{aligned}
\text { Rent }= & \text { production volume } \\
& \times(\text { international market unit price }- \text { average unit production cost })
\end{aligned}
$$

We use the per capita resource rent, which is an appropriate measure of effective rents. A higher amount of resource rents per person makes internal struggles to capture the state more profitable, ceteris paribus. Furthermore, using a per capita measure of resource rents instead of a share in GDP or exports reduces the possible problem of endogeneity [see Alexeev and Conrad (2009) and Bhattacharyya and Hodler (2010) for a similar approach]. However, for robustness analysis, we also use the share of oil exports in total exports, which has frequently been used in the resource curse literature [see, e.g., Sachs and Warner (1995)]. The source of the data is Worldbank (2010).

The last variables to be discussed in detail are our measures of decentralization. The theoretical discussion has shown that the federal design may matter for the relationship between decentralization, resource rents, and internal conflicts. Several measurement concepts are used in the literature to find appropriate approximations [see, e.g., Treisman (2002) and Rodden (2004)]. In general, decentralization is viewed as the devolution of authority towards sub-national governments, with total government authority over society and economy perceived as fixed. Attempts to define and measure decentralization have focused on fiscal authority rather than political autonomy. In our context, we are interested in both. The degree of local autonomy should be important as well as the local budgetary power.

We refer to decentralization measures provided by Daniel Treisman to capture several dimensions of political decentralization [see Treisman (2008) and Fan et al. (2009)]. The data set builds upon earlier work by Lijphart (1984) and Elazar (1995). A first measure of political decentralization is a dummy variable for those countries that have a federal constitution. ${ }^{5}$ Currently, 25 countries are classified as federal countries, of which 18 are included in our analysis.

To measure the degree of local autonomy, Treisman has created several dummy variables based on the constitutions of countries. Two variables are relevant for our

\footnotetext{
${ }^{5}$ The following criteria have to be fulfilled to be counted as a federal country: Countries have at least two levels of government, which share parts of the executive and legislative authority; sub-national governments have representation in the federal parliament (second chamber); there is a requirement to obtain sub-national consent for constitutional amendments; a constitutional judiciary resolves disputes between organs of state; institutions foster collaboration [see Watts (2008)].
} 
research question. A sub-national legislature is said to have residual authority if the constitution assigns the exclusive right to legislate on issues that are not specifically assigned to one level of government. This is a very strong kind of political decentralization. Another measure captures the autonomy of a sub-national legislature. It is said to exist if the constitution reserves exclusive decision-making power on any specific task to sub-national governments.

Decentralization measures reflecting fiscal authority can be approximated by using measures of fiscal decentralization, which can be calculated from the IMF Government Finance Statistics. For our analysis, we refer to the degree of expenditure decentralization, which is the ratio of expenditures of sub-national governments to total government expenditures. This indicator is commonly used in the literature on decentralization and development [see, e.g., Davoodi and Zou (1998)] or decentralization and conflict [see, e.g., Brancati (2006b)]. However, this indicator does not necessarily reflect sub-national governments' budgetary autonomy, since the central government may determine spending at the local level through its own legislation. To capture these effects, a commonly used measure based on budgetary accounts is the so-called vertical imbalance. This measure is the ratio of central government transfers to sub-national government expenditures, and is therefore a measure of the transfer dependence of sub-national governments. Note that a higher value of this measure indicates lower sub-national budgetary autonomy, while all other decentralization measures are defined such that a higher value represents a higher degree of decentralization. To make interpretation of coefficients easier, we rescale the vertical imbalance measure so that a higher value indicates higher sub-national fiscal independence. The vertical imbalance

measure is particularly interesting in our context, since it also reflects the importance of intergovernmental transfers. Transfers redistribute financial resources between regions in order to equalize living standards, which may reduce the risk of conflict.

\subsection{Empirical strategy}

Our empirical approach to investigate the relationship between natural-resource rents, decentralization, and the risk of internal conflict consists of two steps. In the first step we analyze a cross-section of countries using averaged data for the period 1984-2000. Thereby, we examine the variation in the risk of conflict between countries. The second step is to analyze (dynamic) panel data, which focus on the within-country variation over time. The basic regression model in the cross-section has the following form:

$$
C O N F L I C T_{i}=\alpha+\sum_{j=1}^{k} \beta_{j} X_{j, i}+\gamma_{1} R E S_{i}+\gamma_{2} D E C_{i}+\gamma_{3} R E S_{i} \times D E C_{i}+\epsilon_{i} .
$$


Here, CONFLICT $T_{i}$ represents the rescaled ICRG index of the risk of internal conflict in country $i, X_{i}$ are $k$ exogenous control variables affecting the risk of conflict, $R E S_{i}$ represents the different measures of resource rents, $D E C_{i}$ represents different measures of political and fiscal decentralization, $R E S_{i} \times D E C_{i}$ represents the corresponding interaction variables, $\alpha$ is a constant, and $\epsilon_{i}$ is the error term. It is important to mention that we refrain from using the whole available data set (1984-2004) in the cross-section, since we cannot consider time effects. Time effects are quite important in our study, since the terror attacks on $9 / 11$ have increased the sensitivity of the surveyed experts to the terror risk, causing a general increase in the perceived risk of internal conflict in the Western world since then. Consequently, we have used only data until 2000 to build the cross-section data set.

Subsequent to the cross-section estimations, the second step of the analysis is to investigate a panel of countries. Here we are able to use all available data (1984-2004), since time dummies capture the (common) $9 / 11$ effect. The estimation equation for $N$ countries and $T$ time periods, where countries are indexed by $i$ and time by $t$, has the following form:

$$
\begin{aligned}
\operatorname{CONFLICT}_{i, t}= & \operatorname{CONFLICT}_{i, t-1,2}+\sum_{j=1}^{k} \beta_{j} X_{j, i, t}+\gamma_{1} R E S_{i, t}+\gamma_{2} D_{E} C_{i, t} \\
& +\gamma_{3} \operatorname{RES}_{i, t} \times D E C_{i, t}+\alpha_{i}+\mu_{t}+\epsilon_{i, t}
\end{aligned}
$$

The empirical model looks similar to equation (2), but we now consider lagged dependent variables $\left(C O N F L I C T_{i, t-1,2}\right)$, since the risk of conflict is persistent over time. In doing so, we follow the most influential studies in the field, such as Fearon and Laitin (2003), Collier and Hoeffler (2004), and Esteban et al. (2012a). Moreover, equation (3) considers country fixed effects $\left(\alpha_{i}\right)$ and time fixed effects $\left(\mu_{t}\right)$. Using country fixed effects has several advantages, which are important for this analysis. First of all, such regressions focus on the within-country variation in the data, which is a more appropriate approach to test the theoretical predictions than the between-country variations in a standard cross-section analysis. Moreover, country fixed effects are able to eliminate unobserved heterogeneity between countries [Baltagi (2005)]. This is very important for the quality of the analysis, since there are numerous factors affecting the risk of internal conflict that we cannot control, increasing the risk of omitted-variable bias. For example, geographic factors are difficult to consider in an econometric analysis, but can affect internal conflicts. Access to the sea might be a cause for landlocked ethnic groups to engage in conflict, or different ethnic groups might fight for water after a drought. Furthermore, geography is particularly important in our context in that oil and gas resources are point resources. In large countries such as Sudan and Nigeria the unequal geographic distribution of resources is a cause of internal conflicts, while geography is less important in small countries such as Kuwait. All these time-invariant 
country-specific determinants of the risk of conflict are captured by the country dummies. Time fixed effects are relevant for two reasons: (1) the increased perception of the risk of terror after $9 / 11$, and (2) global cycles in resource prices, which affect the countries' resource rents.

The set of control variables is inspired by Fearon and Laitin (2003) and Brunnschweiler and Bulte (2009). We control for the logarithm of the GDP per capita as a proxy for a state's overall financial, administrative, and military capabilities, and as a proxy for higher development with less disadvantages from inaccessible terrain and better integrated rural societies. Another control that explicitly incorporates terrain issues is the share of arable land in the total area of a country. In countries with large mountains or deserts, the share of arable land is low, which we expect to increase the risk of conflict due to terrain disadvantages and the resource land itself. ${ }^{6}$ Moreover, we control for the log of population and the degree of ethnic fractionalization [Alesina et al. (2003)]. Another control, which is less observed in the literature, is the share of Protestants in the total population. Protestant societies are, for example, on average better educated [Becker and Woessmann (2009)], have better institutions [La Porta et al. (1999)], and have less corruption [Treisman (2000)], which might mitigate the risk of conflict. Another standard control is the share of young men in the total population. This age group is typically involved in conflicts. We implement this control by including the youth unemployment rate. The Jasmine Revolution in Tunisia (2010 2011), which flashed over North Africa and the Middle East, has demonstrated how youth unemployment facilitates civil resistance. A further standard control is the level of democracy measured by the POLITY2 index. A list of the countries in our sample, data sources, definitions of variables, and summary statistics are presented in the appendix in tables A.1-A.3.

Ross (2004) and Brunnschweiler and Bulte (2009) argue that the direction of causality between resource rents and the risk of conflict is not very clear. Measuring resource wealth as a share of GDP or exports in conflict-resource regressions is potentially affected by an endogeneity problem. Civil wars destroy manufacturing capacity of a country, leading to higher dependence on resource wealth (as a share of GDP or exports). In such a situation, it would be difficult to interpret the association between resource wealth and conflict as causality. In our analysis this issue is not of high relevance, for two reasons: (1) we use point resource rents in per capita terms, which are more immune to the possible reverse effect from conflict incidents than are rents in GDP or export values, and (2) we employ a difference GMM estimator in a dynamic

\footnotetext{
${ }^{6}$ Fearon and Laitin (2003) use a geographic index that classifies countries according to how mountainous they are. This measure has the disadvantage that it only captures the possible effects of rough terrain, not the potential for conflicts over land as a resource in itself. Moreover, our indicator varies over time; therefore we can include it in the country-fixed-effects panel regressions.
} 
panel data model that incorporates possible endogeneity [Arellano and Bond (1991)]. In this, the resource variable and the lagged dependent variables are treated as endogenous regressors and instrumented by their lagged differences.

\subsection{Cross-section estimates}

The first step of our analysis is to investigate the effect of natural resources and decentralization on the risk of internal conflict in a cross-section of countries. We use four different measures of resource rents: the logarithm of oil rents per capita in constant US\$, the logarithm of gas rents per capita, the sum of oil and gas rents (in logs), and the logarithm of forest rents per capita. In addition, we consider oil exports as a share of total exports to make our results comparable with former studies such as Sachs and Warner (1995). In these explorative benchmark estimations, we consider decentralization by including a dummy variable for federal countries. The above-mentioned alternative indicators reflecting different kinds of political and fiscal decentralization are implemented afterwards. Table 1 reports the results we obtain if we estimate equation (2) without the interaction variable, thereby focusing on the unconditional effects of resource rents and decentralization on the risk of internal conflict.

Most importantly, the signs of the coefficients of the resource rent variables are positive, implying that countries with higher natural-resource abundance have a higher risk of internal conflict. However, the effect is statistically significant at conventional confidence levels only in the cases of oil rents per capita (column 1) and the sum of oil and gas rents per capita (column 3). The coefficient of the share of oil exports in total exports is negative, but insignificant. Although we use the ICGR index of the risk of conflicts instead of binary civil war data, our estimations support the findings of Fearon and Laitin (2003) and others implying that natural resources can be a curse.

The opposite is true for decentralization. As discussed in sections 2 and 3, decentralization can reduce conflict and secessionism. From a theoretical point of view, however, this need not necessarily be the case. On the one hand, decentralization brings the government closer to the people and increases opportunities to participate in government [Oates (1972)], while, on the other hand, decentralization encourages the growth of regional parties [Kymlicka (2006)] and it might strengthen local ethnic elites [Bardhan (2002)]. The net effect of decentralization on the risk of internal conflict is thus ambiguous. In our estimations the coefficient of the federal dummy variable is negative and significantly different from zero in all specifications, implying that the risk of internal conflict is smaller in federations. Interestingly, the size of the effect seems to be quite large: the coefficient is close to unity. Our estimations imply that the index of the risk of internal conflict (which ranges from 0 to 12 ) is approximately 1 index point smaller 
Table 1: Cross-section results I: Resource rents, decentralization, and conflict (1984-2000)

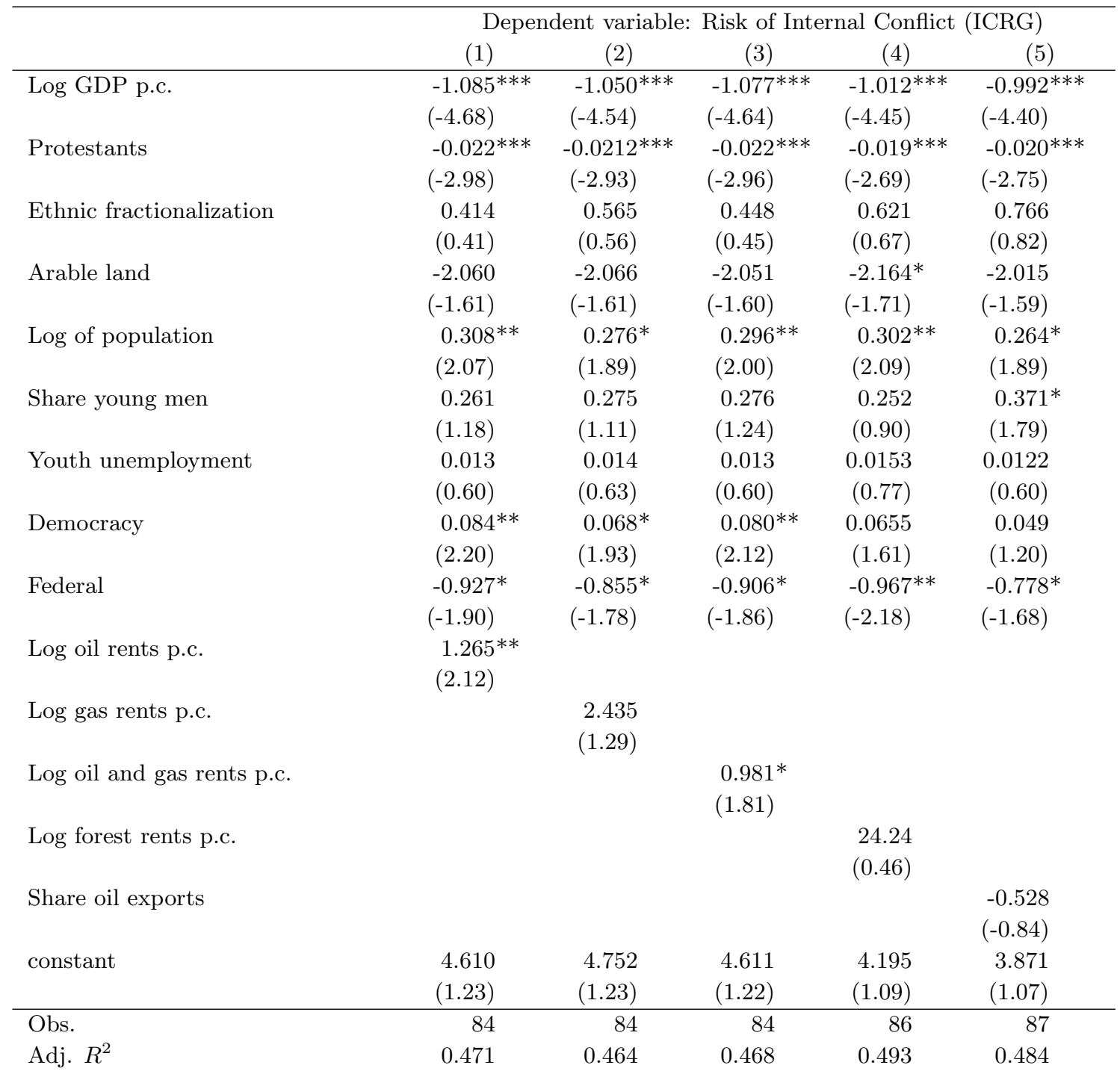

Note: $t$-values are reported in parentheses; standard errors are calculated using White correction; ***, ${ }^{* *}$, and $*$ indicate significance at $1 \%, 5 \%$, and $10 \%$, respectively.

in federal countries. To take an illustrative example: the existence of a federal constitution would explain the difference in the risk of internal conflict between Spain (ICRG index: 4.1) and South Africa (ICRG index: 5.1) after controlling for other factors.

To sum up: both major variables in our study - natural-resource rents and decentralization - are significant determinants of the risk of conflict and support the findings of earlier studies such as Collier and Hoeffler (2005) and Brancati (2006b) among others. However, the major research question of our analysis is whether decentralization mitigates the negative effects from natural resources. It remains, therefore, to study the 
joint effect.

Table 2 summarizes the regression results based on oil and gas rents per capita, where we estimate the fully specified empirical model as proposed by equation (2). ${ }^{7}$

In column (1) we consider a dummy variable for federal countries, in columns (2) and (3) we consider Treisman's indicators of "sub-national autonomy" and "residual authority", in column (4) the degree of expenditure decentralization, and in column (5) the vertical imbalance. The most important observation is that the interaction variable (resource $\times$ decentralization) has a negative coefficient in all specifications. In the case of the measures of political decentralization (columns 2 and 3), the effect is significantly different from zero. At the same time, the coefficient of the resource rent variable is positive and significant; therefore it is easy to interpret the coefficients as marginal effects: resource rents increase the risk of internal conflict in unitary countries by one index point, while political decentralization in terms of sub-national autonomy or residual authority reduces this effect by approximately four index points, ending up on balance in a beneficial net effect of resource rents in federations. Thus, while natural resources are a curse for unitary states, they are a blessing for federations. In other words: (political) decentralization can mitigate the negative effects from naturalresource rents. It is worth mentioning that we find no significant effects of our measures of fiscal decentralization in the cross-section of countries.

Before we continue with the panel data estimates, let us briefly comment on our control variables. The coefficient of the GDP per capita is negative and statistically significant, implying that developed countries have a lower risk of conflict. Obviously, we cannot claim this to be a causal effect, since the risk of internal conflict has a feedback effect on investment and, thus, income. Our newly proposed control variable - the share of Protestants - has a negative and significant coefficient, in line with our hypothesis. The degree of ethnic fractionalization has the expected positive sign, but is significant only in one of the ten regressions (Tables 1 and 2 taken together). This finding is in line with Fearon and Laitin (2003). Note, however, that recent studies by Esteban and Ray (2011) and Esteban et al. (2012a, 2012b) show that this result is related to the measure of ethnic diversity. Our terrain variable - the share of arable land in the total area - has a negative coefficient, which is significant in some specifications. This result is quite suggestive: the lower the pressure of scarcity in arable land, the lower is the risk of internal conflict. The logarithm of the total population is positive

\footnotetext{
${ }^{7}$ Due to space limitations, we are not able to present all results of the estimations we employed. We have five different resource variables and five decentralization measures of decentralization, so that a full table of results would consist of a confusing total of 25 columns. Therefore, we have decided to concentrate on the log of oil and gas rents p.c. Our choice is justified by the fact that some of the big oil exporters are missing in our data set. Just concentration on oil would be therefore somewhat disputable. By including gas rents in the resource rent variable we have an indicator that is more meaningful for our sample of countries. By focusing on just one resource rent variable, we are now able to distinguish between the different decentralization measures.
} 
Table 2: Cross-section results II: Resource rents, decentralization, and conflict (1984-2000)

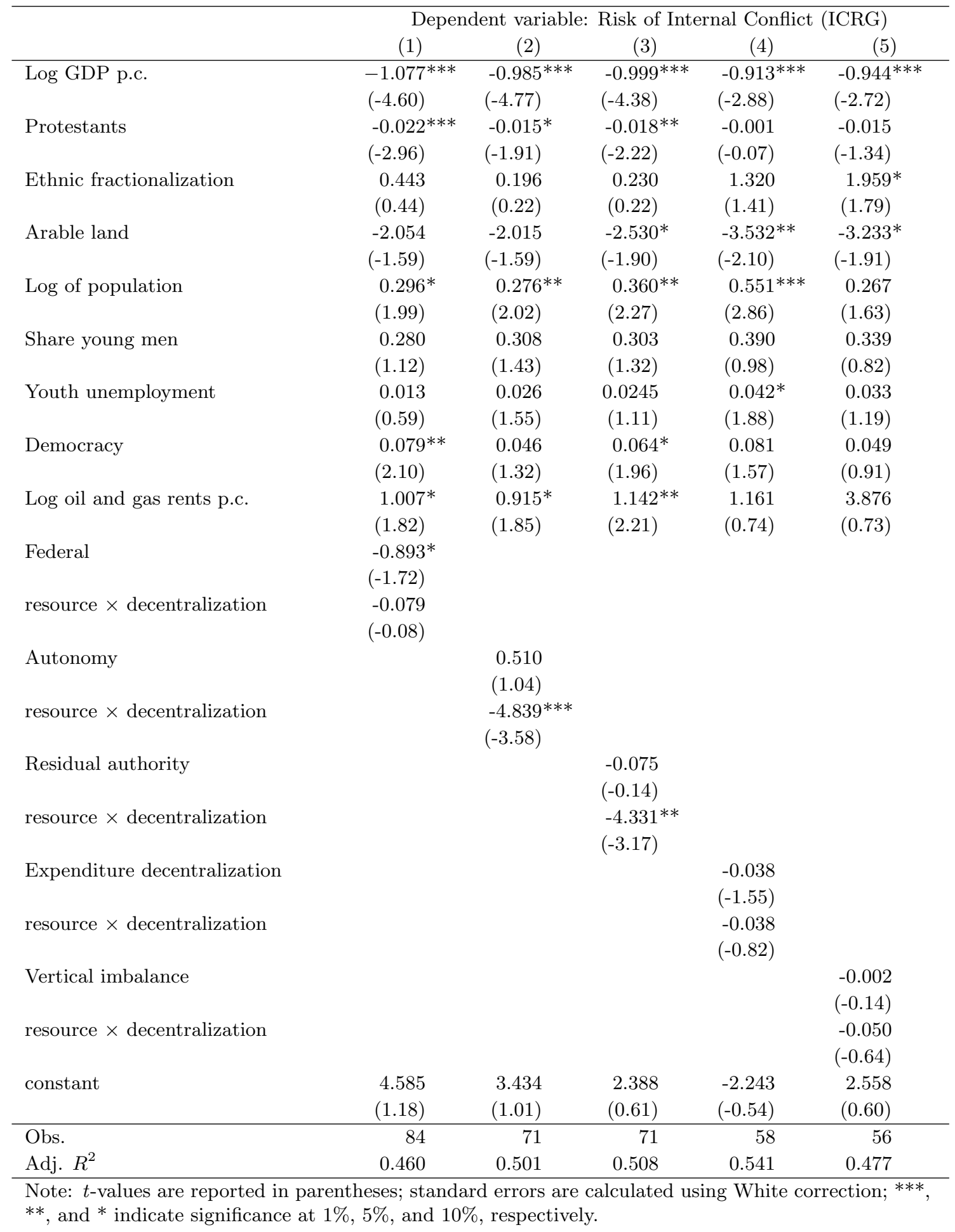


and statistically significant, which is in line with Esteban et al. (2012a) and others. The share of young men and the youth unemployment rate have the expected positive coefficients, but are significant only once in each case. The POLITY2 index as our measure of democracy has a positive coefficient, which is significant in five out of ten specifications. At a first glance this result is somewhat puzzling, but Fearon and Laitin (2003) find quite similar effects on the determinants of civil war. One argument that might explain the unexpected sign is the inverted-U-shaped relationship between democracy and conflict as discussed by Hegre et al. (2001) and Muller and Weede (1990). Full autocracy and full democracy should go along with a low risk of conflict, since highly autocratic regimes can repress dissent and thus avoid civil violence, while highly democratic societies can solve problems peacefully. For middle values of the POLITY2 index, we can thus make no clear predictions. All in all, our controls show quite similar effects if we compare our study with others. The adjusted $R^{2}$ shows that we can explain about $50 \%$ of the variation in the risk of internal conflict, which seems to be quite high in light of the numerous factors we cannot control in a cross-section analysis. Note that the adjusted $R^{2}$ improves on including the interaction variables, implying that the effect of decentralization on the risk of conflict is important.

\subsection{Panel evidence}

The cross-section analysis presented in the previous subsection suggests that decentralization is a useful instrument to mitigate the increased risk of conflict caused by natural-resource rents. However, the regressions focus on between-country variations, while the theoretical arguments focus on changes within countries over time. Therefore, a panel data analysis is a more appropriate framework for our study. In addition, an important advantage of panel data models is the possibility to eliminate unobserved heterogeneity between countries by including country fixed effects. We do so by estimating equation (3). Note that we use the whole data set covering the period from 1984 to 2004, since we are able to control for common time effects. We focus on the logarithm of oil and gas rents per capita. Our controls are similar to the cross-section estimates, with the exception of time-invariant variables, which are dropped from the regression due to collinearity with the country fixed effects. Since the risk of internal conflict is persistent over time, we consider lags of the dependent variable, in line with Fearon and Laitin (2003) among others. We have chosen the number of lags to equal two. Using just a one-period lag, we still have serial correlation in the errors, which disappears on including an additional lag. This implies that there are some factors in the conflict variable that are not well explained by the control variables, but by the past experiences with conflict.

As a baseline regression, we employ fixed effects OLS estimations. Since OLS results 
might be biased in dynamic panel data models [Nickell (1981)], we repeat the estimations using a difference GMM estimator [Arellano and Bond (1991)]. Last but not least, we have used one-year-lagged values of the resource rent variable, the decentralization measure, the interaction term, and the democracy index, since conflicts might break out with a time lag. Again, our approach is in line with the literature, such as Fearon and Laitin (2003). Table 3 presents the results, where columns (1)-(5) report OLS estimates, columns (6)-(10) the difference GMM estimates, and columns (11)-(15) the GMM estimates with lagged independent variables.

In line with the findings of the cross-section estimations, the interaction term of the resource rent variable and the different decentralization measures is always negative. In the OLS regressions the effect is statistically significant for the measures of political decentralization sub-national autonomy (column 2) and residual authority (column 3). In the difference GMM estimations the effect is only significant for residual authority (column 8). Interestingly, if we consider lags of the independent variables, we find significant interaction effects for the federal dummy (column 11), sub-national autonomy (column 12), residual authority (column 13), and the degree of expenditure decentralization. The coefficient of the resource rent variable is always positive, but only significant in some specifications of the difference GMM estimates using lagged independent variables. All in all, the panel data analyses suggest that decentralization, particularly political decentralization, reduces the risk of conflict caused by natural resources.

An important robustness check is to include a common time trend variable in the panel regressions. Our measure of the risk of internal conflict is partially based on subjective rankings. One might argue that the polled experts have reacted with their ratings to an increased general risk of terror after the attacks of $9 / 11$. Indeed, our indicator for the risk of internal conflict has increased in our observation period on average, which cannot be captured by time dummy variables. Thus, we compare our dynamic panel regressions using time dummy and time trend variables. Table A.4 in the appendix presents the results. In the case of the federal dummy and the measure of sub-national autonomy, the sign and significance of the interaction variable are almost unaffected by inclusion of a common time trend. This supports our results from the cross-section, which cannot be biased by common time effects. Recall that we concentrate on the pre-9/11 period in these regressions. Only for the measures of residual authority and expenditure decentralization is the coefficient of the interaction variable not significant. 


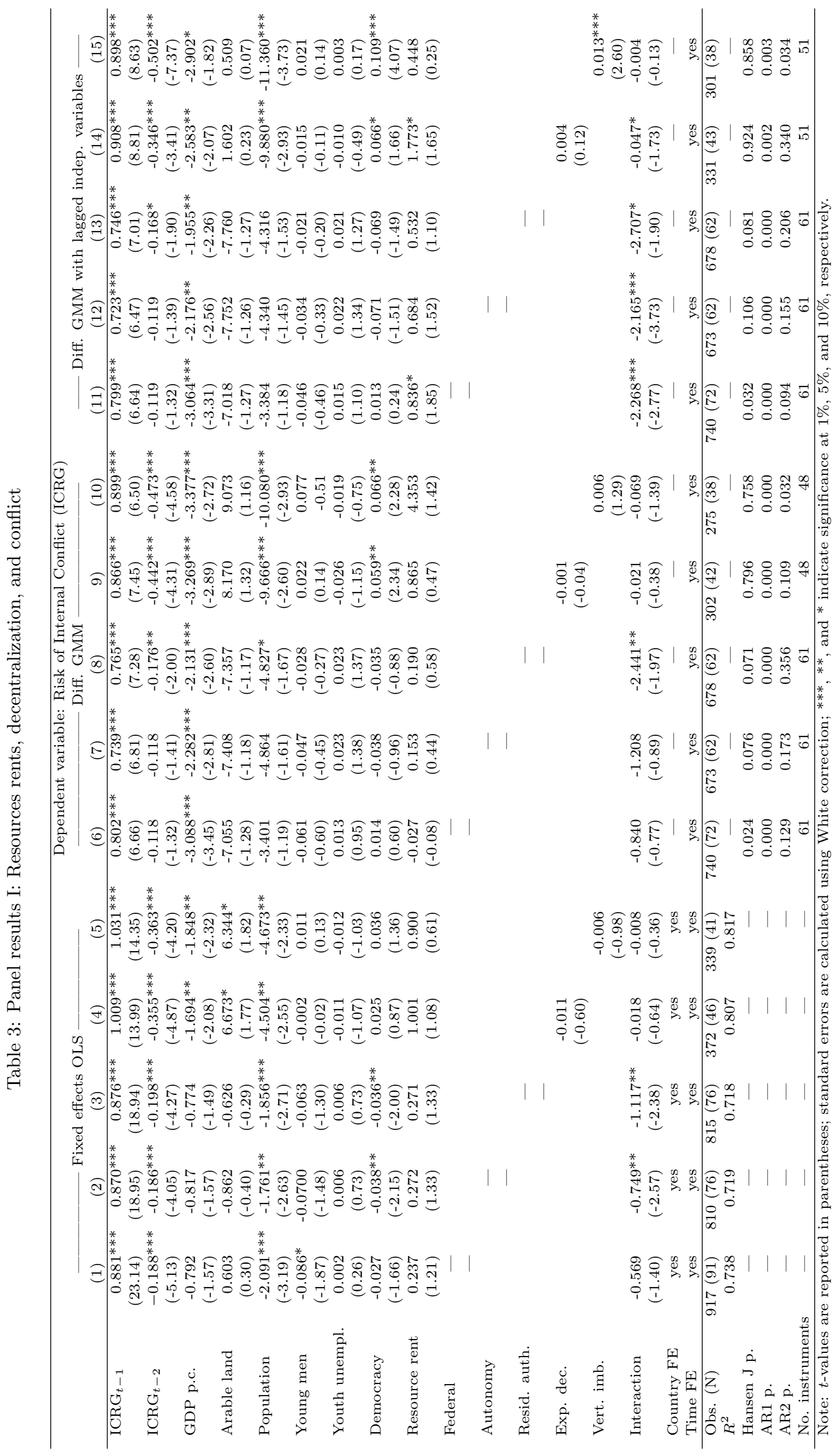




\section{Conclusion}

Natural resources have been one of the main drivers of civil wars and conflicts in the last decades. The examples are numerous. Sierra Leone, Congo, Liberia, and Angola have all experienced severe civil wars because of natural resources. The oil revenues are being used by the Angolan government for the civil war with the rebel UNITA movement. The eighteen-year civil war in Sudan, which took the life of more than two million people, was over oil resources. The current conflict in the Niger delta, which arose in the early 1990s, is another example of oil-driven conflict.

We investigated the conflict-natural-resources relation for 91 countries from 1984 to 2004. Our cross-country and panel estimations show that there is a significant increasing effect of lootable resources on the risk of internal conflict (civil war, terrorism, and civil unrest). Our main contribution, however, is presenting a possible solution for the conflict-resources problem. The empirical results show that political decentralization is a relevant factor in breaking down the relationship between natural-resource rents and internal conflict: the direct effect of resource rents on civil war and internal conflicts is positive and statistically significant, but political decentralization can limit this destructive effect. These results are robust to controlling for other main determinants of conflict such as GDP per capita, ethnic fractionalization, the youth unemployment rate, the share of young people in the total population, an indicator for level of democracy, and the share of Protestants. In addition, panel regressions enable us to control for unobservable country factors such as historical or geographical differences, as well as common time shocks, by including country and time fixed effects. We have also taken into account the possibility of reverse feedback from conflict on some of our main variables by using the difference GMM estimation methodology and lags of independent variables in panel estimations. The GMM method also enables us to control for the persistence of our dependent variable (conflict risk).

The policy conclusion from this study is straightforward: governments of resourcerich countries, especially with lootable resources such as oil, can reduce the risk of destructive civil wars and separation movements by giving their citizens or their elected representatives more power in public decision making, i.e., political decentralization. The resource curse presenting in our study through resource-driven conflicts can be controlled by increasing the role of local governors and local electorates in decision making in resource-rich countries. 


\section{References}

Acemoglu, D. and J. Robinson (2000). Why did the West extend the franchise? Growth, inequality and democracy in a historical perspective. Quarterly Journal of Economics, 115(4), pp. 1167-1199.

Alesina, A., A. Devleeschauwer, W. Easterly, S. Kurlat, and R. Wacziarg (2003). Fractionalization. Journal of Economic Growth, 8(2), pp. 155-194.

Alesina, A. and G. Tabellini (1990). Voting on the Budget Deficit. American Economic Review, 80(1), pp. 37-49.

Alexeev, M. and R. Conrad (2009). The Elusive Curse of Oil. Review of Economics and Statistics, 91(3), pp. 586-598.

Andersen, J. J. and S. Aslaksen (2012). Oil and political survival. Journal of Development Economics, 100(1), pp. 89-106.

Arellano, M. and S. Bond (1991). Some Tests of Specification for Panel Data: Monte Carlo Evidence and an Application to Employment Equations. Review of Economic Studies, 58(2), pp. 277-297.

Baldwin, R. E. and P. Krugman (2004). Agglomeration, integration and tax harmonisation. European Economic Review, 48(1), pp. 1-23.

Baltagi, B. H. (2005). Econometric Analysis of Panel Data. Chichester: Wiley.

Bardhan, P. (2002). Decentralization of Governance and Development. Journal of Economic Perspectives, 16(4), pp. 185-205.

Becker, S. O. and L. Woessmann (2009). Was Weber Wrong? A Human Capital Theory of Protestant Economic History. Quarterly Journal of Economics, 124(2), pp. 531-596.

Bermeo, N. (2005). Position paper for the working group on federalism, conflict prevention and settlement. Technical report, prepared for the International Conference on Federalism, 3-5 March 2005, Brussels.

Besley, T. and T. Persso (2010). State Capacity, Conflict, and Development. Econometrica, 78(1), pp. 1-34.

Bhattacharyya, S. and R. Hodler (2010). Natural Resources, Democracy and Corruption. European Economic Review, 54(4), pp. 608-621.

Bird, R. (2010). Is Decentralization "Glue" or "Solvent" for National Unity? International Studies Program Working Paper Series 10-03, Andrew Young School of Policy Studies, Georgia State University.

Blattman, C. and E. Miguel (2010). Civil War. Journal of Economic Literature, 48(1), pp. $3-57$. 
Boschini, A. D., J. Pettersson, and J. Roine (2007). Resource Curse or Not: A Question of Appropriability. Scandinavian Journal of Economics, 109(3), pp. 593-617.

Brancati, D. (2006a). Decentralization: Fueling the Fire or Dampening the Flames of Ethnic Conflict and Secessionism? International Organization, 60, pp. 651-685.

Brancati, D. (2006b). Decentralization: Fueling the Fire or Dampening the Flames of Ethnic Conflict and Secessionism? International Organization, 60(3), pp. 651-685.

Brunnschweiler, C. N. (2008). Cursing the Blessings? Natural Resource Abundance, Institutions, and Economic Growth. World Development, 36(3), pp. 399-419.

Brunnschweiler, C. N. and E. H. Bulte (2009). Natural Resources and Violent Conflict: Resource Abundance, Dependence, and the Onset of Civil Wars. Oxford Economic Papers, 61(4), pp. 651-674.

Buhaug, H., K. Gleditschm, H. Holtermann, G. Østby, , and A. F. Tollefsen (2012). It's the local economy, stupid! Geographic wealth dispersion and conflict outbreak location. Journal of Conflict Resolution, 55(5), pp. 814-840.

Chamarbagwala, R. and H. E. Morán (2011). The Human Capital Consequences of Civil War: Evidence from Guatemala. Journal of Development Economics, 94(1), pp. $41-61$.

Collier, P. (1999). On the Economic Consequences of Civil War. Oxford Economic Papers, 51(1), pp. 168-83.

Collier, P., V. L. Elliott, H. Hegre, A. Hoeffler, M. Reynal-Querol, and N. Sambanis (2003). Breaking the Conflict Trap: Civil War and Development Policy. World Bank Policy Research Report. New York: Oxford Univ. Press.

Collier, P. and A. Hoeffler (1998). On Economic Causes of Civil War. Oxford Economic Papers, 50(4), pp. 563-73.

Collier, P. and A. Hoeffler (2004). Greed and Grievance in Civil War. Oxford Economic Papers, 56(4), pp. 563-595.

Collier, P. and A. Hoeffler (2005). Resource Rents, Governance, and Conflict. Journal of Conflict Resolution, 49(4), pp. 625-633.

Collier, P. and A. Hoeffler (2012). High-value natural resources, development, and conflict: Channels of causation. In P. Lujala and S. A. Rustad (editors), In HighValue Natural Resources and Peacebuilding, pp. 297-312. London: Earthscan.

Collier, P., A. Hoeffler, and D. Rohner (2009). Beyond greed and grievance: Feasibility and civil war. Oxford Economic Papers, 61(1), pp. 1-27.

Corden, P. and J. Neary (1982). Booming Sector and de-industralisation in a small open economy. Economic Journal, 92(368), pp. 825-848. 
Davoodi, H. and H. Zou (1998). Fiscal Decentralisation and Economic Growth: A Cross Country Study. Journal of Urban Economics, 43(2), pp. 244-257.

Deiwiks, C., L. Cederman, and K. Gleditsch (2012). Inequality and conflict in federations. Journal of Peace Research, 49(2), pp. 289-304.

Dreher, A. and J. A. V. Fischer (2010). Government Decentralization As A Disincentive For Transnational Terror? An Empirical Analysis. International Economic Review, 51(4), pp. 981-1002.

Dreher, A. and J. A. V. Fischer (2011). Does government decentralization reduce domestic terror? An empirical test. Economics Letters, 111(3), pp. 223-225.

Ebel, R. and S. Yilmaz (2003). On the Measurement and Impact of Fiscal Decentralization. In J. Martinez-Vazquez and S. Yilmaz (editors), Public Finance in Developing and Transitional Countries, Essays in Honour of Richard Bird, pp. 101-126. Cheltenham: Elgar.

Elazar, D. J. (1995). Federalism: An Overview. Pretoria: HSRC Publishers.

Esteban, J., L. Mayoral, and D. Ray (2012a). Ethnicity and Conflict: An Empirical Study. American Economic Review, 102(4), pp. 1310-42.

Esteban, J., L. Mayoral, and D. Ray (2012b). Ethnicity and Conflict: Theory and Facts. Science, 336(6083), pp. 858-865.

Esteban, J. and D. Ray (2011). Linking Conflict to Inequality and Polarization. American Economic Review, 101(4), pp. 1345-74.

Fan, C. S., C. Lin, and D. Treisman (2009). Political Decentralization and Corruption: Evidence from Around the World. Journal of Public Economics, 93(1-2), pp. 14-34.

Fearon, J. D. (2004). Why do Some Civil Wars Last so Much Longer than Others? Journal of Peace Research, 41(3), pp. 275-301.

Fearon, J. D. (2005). Primary Commodity Exports and Civil War. Journal of Conflict Resolution, 49(4), pp. 483-507.

Fearon, J. D. and D. D. Laitin (2003). Ethnicity, Insurgency, and Civil War. American Political Science Review, 97(1), pp. 75-90.

Frey, B. (2004). Decentralization as a disincentive for terror. European Journal of Political Economy, 20(2), pp. 509 - 515.

GTZ (2006). Decentralization and Conflicts: A Guideline. Eschborn, Federal Ministry for Economic Cooperation and Development.

Hegre, H., T. Ellingsen, S. Gates, and N. P. Gleditsch (2001). Toward a Democratic Civil Peace? Democracy, Political Change, and Civil War, 1816-1992. American Political Science Review, 95(1), pp. 33-48. 
Humphreys, M. (2005). Natural Resources, Conflict, and Conflict Resolution. Journal of Conflict Resolution, 49(4), pp. 508-537.

Iimi, A. (2005). Decentralization and Economic Growth Revisited: An Empirical Note. Journal of Urban Economics, 57(3), pp. 449-461.

Iimi, A. (2007). Escaping from the Resource Curse: Evidence from Botswana and the Rest of the World. IMF Staff Papers, 54(4), pp. 663-699.

Isham, J., M. Woolcock, L. Pritchett, and G. Busby (2005). The Varieties of Resource Experience: Natural Resource Export Structures and the Political Economy of Economic Growth. World Bank Economic Review, 19(2), pp. 141-174.

Janus, T. (2012). Natural resource extraction and civil conflict. Journal of Development Economics, 97(1), pp. 24-31.

Kymlicka, W. (2006). Is Federalism a Viable Alternative to Secessionism? In P. B. Lehning (editor), Theories of Secessionism, pp. 111-150. New York: Routledge Press.

La Porta, R., F. L. de Silane, A. Shleifer, and R. Vishny (1999). The Quality of Goverment. Journal of Law, Economics and Organization, 15(1), pp. 222-279.

Le Billon, P. (2001). The Political Ecology of War: Natural Resources and Armed Conflicts. Political Geography, 20(5), pp. 561-584.

Lessmann, C. (2009). Fiscal Decentralization and Regional Disparity: Evidence from Cross-section and Panel Data. Environment and Planning A, 41(10), pp. 2455-2473.

Lessmann, C. (2012). Regional inequality and decentralization: an empirical analysis. Environment and Planning A, 44(6), pp. 1363-1388.

Lessmann, C. (2013). Regional inequality and internal conflict. CESifo Working Paper 4112.

Lessmann, C. and G. Markwardt (2010). One Size Fits All? Decentralisation, Corruption and the Monitoring of Bureaucrats. World Development, 38(4), pp. 631-646.

Lijphart, A. (1984). Democracies. New Haven and London: Yale University Press.

Linz, J. and A. Stepan (2000). Federalism, Democracy, and Inequality: With Special Reference to the Classic Outlier - the USA. Working papers, Paper presented at the International Political Science Association, August 1-5, Quebec City, Canada.

Lujala, P. (2010). The spoils of nature: armed civil conflict and rebel access to natural resources. Journal of Peace Research, 47(1), pp. 15-28.

Marshall, M. and T. R. Gurr (2005). Peace and Conflict: A Global Survey of Armed Conflicts, Self Determination, Movements, and Democracy. Working papers, Center for International Development and Conflict Management, University of Maryland. 
Marshall, M. G. and K. Jaggers (2009). Polity IV Project. Political Regime Characteristics and Transitions (1800 to 2007). Technical report, Center for Systemic Peace.

Mehlum, H., K. Moene, and R. Torvik (2006). Institutions and the Resource Curse. Economic Journal, 116(1), pp. 1-20.

de Mello, L. J. (2000). Fiscal Decentralization and Intergovernmental Fiscal Relations: A Cross-Country Analysis. World Development, 28(2), pp. 365-380.

Muller, E. N. and E. Weede (1990). Cross-National Variation in Political Violence: A Rational Action Approach. The Journal of Conflict Resolution, 34(4), pp. 624-651.

Nickell, S. J. (1981). Biases in Dynamic Models with Fixed Effects. Econometrica, 49(6), pp. 1417-26.

Oates, W. E. (1972). Fiscal Federalism. New York: Harcourt Brace Jovanovich.

Oates, W. E. (1993). Fiscal Decentralization and Economic Development. National Tax Journal, 46(2), pp. 237-243.

Persson, T. and G. Tabellini (1996). Federal Fiscal Constitutions: Risk Sharing and Moral Hazard. Econometrica, 64(3), pp. 623-646.

Prud'homme, R. (1995). The Dangers of Decentralization. World Bank Research Observer, 10(2), pp. 201-220.

Robinson, J. A., R. Torvik, and T. Verdier (2006). Political Foundations of the Resource Curse. Journal of Development Economics, 79(2), pp. 447-468.

Rodden, J. (2004). Comparative Federalism and Decentralization: On Meaning and Measurement. Comparative Politics, 36(4), pp. 481-500.

Rodríguez-Pose, A. and R. Ezcurra (2010). Does Decentralization Matter for Regional Disparities? A Cross-Country Analysis. Journal of Economic Geography, 10(5), pp. 619-644.

Ross, M. L. (2004). What Do We Know about Natural Resources and Civil War? Journal of Peace Research, 41(3), pp. 337-356.

Sachs, J. D. and A. M. Warner (1995). Natural Resource Abundance and Economic Growth. NBER Working Papers 5398, National Bureau of Economic Research, Inc.

Sachs, J. D. and A. M. Warner (2001). The Curse of Natural Resources. European Economic Review, 45(4-6), pp. 827-838.

Schou, A. and M. Haug (2005). Decentralisation in Conflict and Post-Conflict Situations. Working Paper 139, Norwegian Institute for Urban and Regional Research. 
Shankar, R. and A. Shah (2003). Bridging the Economic Divide within Countries a Scorecard on the Performance of Regional Policies in Reducing Regional Income Disparities. World Development, 31(8), pp. 1421-1441.

Shemyakina, O. (2011). The Effect of Armed Conflict on Accumulation of Schooling: Results from Tajikistan. Journal of Development Economics, 95(2), pp. 186 - 200.

Sánchez-Pagés, S. (2006). On the social efficiency of conflict. Economics Letters, 90(1), pp. 96-101.

Soysa, I. d. (2002). Paradise Is a Bazaar? Greed, Creed, and Governance in Civil War, 1989-99. Journal of Peace Research, 39(4), pp. 395-416.

Østby, G., R. Nordås, and J. K. Rød (2009). Regional Inequalities and Civil Conflict in Sub-Saharan Africa. International Studies Quarterly, 53(2), pp. 301-324.

Stewart, F., C. Huang, and M. Wang (2001). Internal Wars in Developing Countries: An Empirical Overview of Economic and Social Consequences. In F. Stewart and V. Fitzgerald (editors), War and Underdevelopment, Vol. 1, pp. 67-103. Oxford, U.K.: Oxford University Press.

Tranchant, J. P. (2007). Decentralization and Ethnic Conflict: The Role of Empowerment. Working Papers 200705, CERDI.

Tranchant, J.-P. (2010). Does Fiscal Decentralization Dampen All Ethnic Conflicts? The heterogeneous Impact of Fiscal Decentralization on Local Minorities and Local Majorities. Working paper, Munich Personal RePEc Archive.

Treisman, D. (2000). The Causes of Corruption: A Cross-National Study. Journal of Public Economics, 76(3), pp. 399-457.

Treisman, D. (2002). Defining and Measuring Decentralization: A Global Perspective. Diskussionspapier, University of California.

Treisman, D. (2008). Decentralization Dataset. http://www.sscnet.ucla.edu/polisci/ faculty/treisman/.

Watts, R. L. (2008). Comparing Federal Systems. Montréal: McGill-Queen's Univ. Press.

Wick, K. and E. Bulte (2006). Contesting resources-rent seeking, conflict and the natural resource curse. Public Choice, 128(2), pp. 457-476.

Worldbank (2010). World Development Indicators 2009. Washington D. C. 
Table A.1: List of countries considered

Albania, Algeria, Argentina, Armenia, Australia, Austria, Bangladesh, Bahrain, Belgium, Bolivia, Botswana, Brazil, Bulgaria, Canada, Chile, Colombia, Costa Rica, Croatia, Cyprus, Czech Republic, Denmark, Dominican Republic, Ecuador, Egypt, El Salvador, Ethiopia, Finland, France, Gabon, Germany, Ghana, Greece, Guatemala, Haiti, Honduras, Hungary, India, Indonesia, Ireland, Israel, Italy, Jamaica, Japan, Kazakhstan, Latvia, Lithuania, Malaysia, Mexico, Moldova, Mongolia, Morocco, Namibia, Netherlands, New Zealand, Nicaragua, Nigeria, Norway, Pakistan, Panama, Papua New Guinea, Peru, Paraguay, Philippines, Poland, Portugal, Romania, Russian Federation, Slovak Republic, Slovenia, Singapore, South Africa, South Korea, Spain, Sri Lanka, Sweden, Switzerland, Syrian Arab Republic, Tanzania, Tunisia, Turkey, Trinidad and Tobago, Thailand, Ukraine, United Arab Emirates, United Kingdom, United States of America, Uruguay, Venezuela, Yemen Republic, Zambia, Zimbabwe.

Table A.2: Summary statistics

\begin{tabular}{lccccc}
\hline Variable & Obs & Mean & Std. Dev. & Min & Max \\
\hline ICRG risk of internal conflict & 917 & 2.28 & 2.27 & 0.00 & 12.00 \\
Log oil rents p.c. & 917 & 0.08 & 0.24 & 0.00 & 2.11 \\
Log gas rents p.c. & 917 & 0.05 & 0.11 & 0.00 & 1.26 \\
Log oil and gas rents p.c. & 917 & 0.12 & 0.27 & 0.00 & 2.37 \\
Log forest rents p.c. & 916 & 0.00 & 0.00 & 0.00 & 0.05 \\
Share oil exports & 894 & 0.09 & 0.17 & 0.00 & 0.97 \\
Federal dummy & 917 & 0.23 & 0.42 & 0.00 & 1.00 \\
Sub-national autonomy & 810 & 0.19 & 0.39 & 0.00 & 1.00 \\
Residual authority & 815 & 0.20 & 0.40 & 0.00 & 1.00 \\
Expenditure decentralization & 372 & 24.88 & 14.82 & 1.76 & 58.73 \\
Vertical imbalance & 339 & 62.86 & 20.98 & 11.73 & 99.61 \\
Log GDP p.c. & 917 & 8.72 & 1.26 & 4.92 & 10.59 \\
Protestants & 913 & 16.88 & 26.23 & 0.00 & 97.80 \\
Ethnic fractionalization & 916 & 0.32 & 0.22 & 0.00 & 0.85 \\
Arable land & 917 & 0.18 & 0.14 & 0.00 & 0.71 \\
Log of population & 917 & 16.56 & 1.37 & 13.14 & 20.80 \\
Share young men & 917 & 8.02 & 0.89 & 5.96 & 14.18 \\
Youth unemployment & 917 & 17.49 & 9.81 & 2.20 & 56.50 \\
Democracy & 917 & 7.72 & 4.00 & -10.00 & 10.00 \\
\hline
\end{tabular}


Table A.3: Data sources \& definitions

\begin{tabular}{|c|c|c|}
\hline Variable & Definition & Source \\
\hline Risk of internal conflict & $\begin{array}{l}\text { The index of the risk of internal conflict is part } \\
\text { of the PRS Group's International Country Risk } \\
\text { Guide (ICRG). It measures the risk of internal } \\
\text { conflict based on three categories: civil war and } \\
\text { coup threat, terrorism and political violence, and } \\
\text { civil disorder. The original index ranges from } 0 \text { to } \\
12 \text {, where the highest value is given to those coun- } \\
\text { tries that have the lowest risk. We have rescaled } \\
\text { the index so that the highest value indicates a high } \\
\text { risk of conflict, to make interpretation easier. }\end{array}$ & $\begin{array}{ll}\text { International } & \text { Coun- } \\
\text { try Risk } & \text { Guide } \\
\text { (ICRG) } & \end{array}$ \\
\hline Log oil rents p.c. & $\begin{array}{l}\text { Natural logarithm of the rents from oil exploita- } \\
\text { tion per capita }\end{array}$ & Worldbank (2010) \\
\hline Log gas rents p.c. & $\begin{array}{l}\text { Natural logarithm of the rents from gas exploita- } \\
\text { tion per capita }\end{array}$ & Worldbank (2010) \\
\hline Log oil and gas rents p.c. & $\begin{array}{l}\text { Natural logarithm of the sum of all rents from oil } \\
\text { and gas exploitation per capita }\end{array}$ & Worldbank (2010) \\
\hline Log forest rents p.c. & $\begin{array}{l}\text { Natural logarithm of the rents from timber pro- } \\
\text { duction per capita }\end{array}$ & Worldbank (2010) \\
\hline Share oil exports & Oil exports as a share of all merchandized exports & Worldbank (2010) \\
\hline Federal & Dummy for countries with a federal constitution. & Treisman (2008) \\
\hline Sub-national autonomy & $\begin{array}{l}\text { Local jurisdictions are said to have a certain } \\
\text { amount of autonomy regarding a given ques- } \\
\text { tion if the constitution reserves to them exclusive } \\
\text { decision-making power on that question. }\end{array}$ & Treisman (2008) \\
\hline Residual authority & $\begin{array}{l}\text { A sub-national legislature is said to have residual } \\
\text { authority if the constitution assigns to it the ex- } \\
\text { clusive right to legislate on issues that are not spe- } \\
\text { cifically assigned to one level of government. }\end{array}$ & Treisman (2008) \\
\hline $\begin{array}{l}\text { Expenditure decentrali- } \\
\text { zation }\end{array}$ & $\begin{array}{l}\text { The degree of expenditure decentralization relates } \\
\text { the sum of sub-national (state and local) govern- } \\
\text { ment expenditures to total government expendi- } \\
\text { tures. }\end{array}$ & IMF GFS \\
\hline Vertical imbalance & $\begin{array}{l}\text { Grant share of sub-national government expendi- } \\
\text { tures. }\end{array}$ & IMF GFS \\
\hline $\log G D P$ p.c. & Log of the GDP per capita in 2005 dollars. & Worldbank (2010) \\
\hline Protestants & $\begin{array}{l}\text { Population share belonging to a Protestant } \\
\text { church. }\end{array}$ & La Porta et al. (1999) \\
\hline Ethnic fractionalization & $\begin{array}{l}\text { Ethnolinguistic fractionalization is computed as } \\
\text { one minus the Herfindahl index of ethnolinguistic } \\
\text { group shares, and reflects the probability that two } \\
\text { randomly selected individuals from a population } \\
\text { belonged to different groups. }\end{array}$ & Alesina et al. (2003) \\
\hline Arable land & Share of arable land in the total area & Worldbank (2010) \\
\hline Log of population & Log of the total population & Worldbank (2010) \\
\hline Share young men & $\begin{array}{l}\text { Share of the male population of ages } 25-29 \text { in the } \\
\text { total population }\end{array}$ & Worldbank (2010) \\
\hline Youth unemployment & $\begin{array}{l}\text { Unemployment youth total (\% of total labor force } \\
\text { ages } 15-24 \text { ) }\end{array}$ & Worldbank (2010) \\
\hline Democracy & Polity2 index as provided by the PolityIV project & $\begin{array}{l}\text { Marshall and Jaggers } \\
(2009)\end{array}$ \\
\hline
\end{tabular}




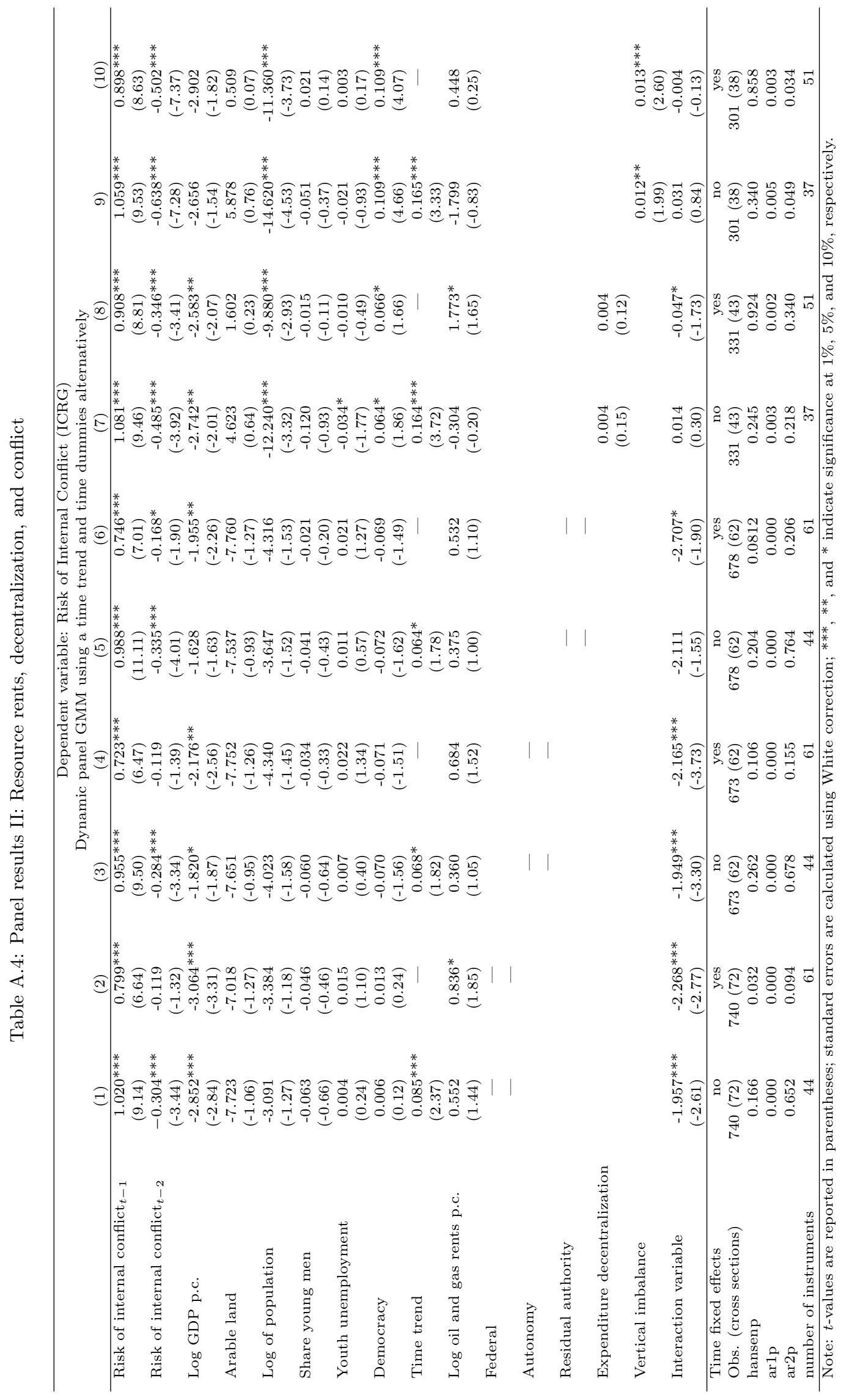

